Nova Southeastern University

Florida

NOVA SOUTHEASTERN

UNIVERSITY

NSUWorks

Marine \& Environmental Sciences Faculty Articles Department of Marine and Environmental Sciences

$8-1-2012$

\title{
The Consumption of DHA During Embryogenesis as an Indicative of the Need to Supply DHA During Early Larval Development: A Review
}

Joana Figueiredo

Universidade de Lisboa - Australia; James Cook University - Townsville, Australia, jigueiredo@nova.edu

Junda Lin

Florida Institute of Technology

Justin Anto

Florida Institute of Technology, James Cook University - Townsville, Australia

Luis Narciso

Universidade de Lisboa - Australia

Find out more information about Nova Southeastern University and the Halmos College of Natural Sciences and Oceanography.

Follow this and additional works at: https://nsuworks.nova.edu/occ_facarticles

Part of the Marine Biology Commons, and the Oceanography and Atmospheric Sciences and Meteorology Commons

\section{NSUWorks Citation}

Joana Figueiredo, Junda Lin, Justin Anto, and Luis Narciso. 2012. The Consumption of DHA During Embryogenesis as an Indicative of the Need to Supply DHA During Early Larval Development: A Review .Journal of Aquaculture Research and Development , (5) : 1 -7.https://nsuworks.nova.edu/occ_facarticles/420. 


\title{
The Consumption of DHA during Embryogenesis as an Indicative of the Need to Supply DHA during Early Larval Development: A Review
}

\author{
Joana Figueiredo ${ }^{1,2,3 *}$, Junda Lin², Justin Anto ${ }^{2,4}$ and Luís Narciso ${ }^{1}$ \\ ${ }^{1}$ Centro de Oceanografia, Universidade de Lisboa, Australia \\ ${ }^{2}$ Florida Institute of Technology, Department of Biological Sciences, Australia \\ ${ }^{3} A R C$ Centre of Excellence for Coral Reef Studies, James Cook University, Australia \\ ${ }^{4}$ School of Marine and Tropical Biology, James Cook University, Australia
}

\begin{abstract}
The establishment of an adequate larval diet for crustacean and fish often involves a series of time-consuming and expensive trial and errors. Despite being nutritionally poor, rotifers and Artemia are the most commonly used preys in larviculture. Whether (and to what extent) the prey needs to be enriched with essential fatty acids differs from species to species. We hypothesized that the DHA content of a newly spawned eggs and its consumption through embryogenesis can be a good indicator of the need to enrich the prey with DHA. In order to assess this hypothesis, we performed a search in the scientific literature and compared DHA consumption through embryogenesis with larval culture success with unenriched and DHA-enriched Artemia nauplii, respectively a prey poor and rich in DHA of fish and crustacean. Data available from previously published studies suggests that, higher the consumption of DHA during embryonic development, greater the requirement of a diet rich in DHA during early larval development; and when, although present, DHA is not consumed during embryogenesis, larvae seem to be able to successfully develop with diet poor in DHA (i.e. using solely their reserves). Further studies will be necessary to better validate this hypothesis, but if confirmed, it may allow a reduction of time and costs associated with the establishment of an adequate larval diet.
\end{abstract}

Keywords: DHA; Embryogenesis; Enrichment; Fatty acid consumption; Larval diet; Profitability

\section{Introduction}

The development of an aquaculture industry relies on the profitability of its culture protocols. The methods utilized to raise a species not only have to be reliable and highly productive, as they have to be relatively inexpensive [1]. This imposes several challenges to producers since a culture protocol that guaranties higher survival is not necessarily the most productive or profitable [2]. For instance, higher stocking densities may generate lower survival, but be more productive than lower stocking densities [2]. One of the greatest expenses for an aquaculture facility is the feeds, particularly the ones destined to the larvae.

\section{The Need for Live Prey}

Most newly hatched marine larvae, particularly marine fish larvae, have an underdeveloped digestive system [3] lacking some proteases such as trypsin, a proteolytic enzyme responsible for 40 $60 \%$ of digestion. Without the necessary amount of trypsin and other proteases, marine larvae require live prey containing these enzymes to facilitate their digestion [4-6]. Additionally, the movement of live preys in the water column is an attractant to larvae, and this is difficult to imitate in artificial diets. For these reasons, artificial diets generally can only be introduced to totally or partially substitute live prey later in development [6]. The rotifer Brachionus spp. and the anostracan brine shrimp Artemia sp are the predominant live prey items in larviculture. Their popularity advents from their small size and established culture techniques $[7,8]$. While heavily utilized, these prey items lack many of the essential fatty acids (lipids) required by marine larvae.

\section{The Role of Lipids and Fatty Acids}

Lipids are fundamentally important for the growth, development and survival of marine species $[9,10]$ : phospholipids are structurally bound in membranes where they fulfill crucial physiological functions; triacylglycerides constitute a major energy reserve that can be rapidly mobilized during periods of nutritional, thermal or osmotic stress; sterols are precursors of hormones. Fatty acids constitute the essential part of triacylglycerides and wax esters, which are the major components of fats and oils [11].

Fatty acid requirements of marine species are known to vary both qualitatively and quantitatively [12,13]. Marine species can convert Eicosapentaenoic Acid (EPA) to Docosahexaenoic Acid (DHA), albeit at low rates not likely to fully meet the high demand for DHA during larval growth [14]. Eicosapentaenoic acid (20:5n-3) is chain elongated to $22: 5 n-3$ and hence to $24: 5 n-3$ (Figure 1). The latter is then converted by the enzyme $\Delta-6$ desaturase to $24: 6 n-3$, which is finally chain shortened by peroxysomal $\beta$-oxidation to DHA (22:6n-3) [14-16] (Figure 1). However, $\Delta-6$ desaturase also actively converts linolenic acid $(18: 3 n-3)$ to $18: 4 n-3$. Thus, both $18: 3 n-3$ and $24: 5 n-3$ are substrates for the same enzyme. Since $18: 3 n-3$ is in higher amounts than $24: 5 n-3$, it will competitively suppress the conversion of EPA (20:5n-3) to DHA (22:6n-3) [14,17] (Figure 1). Also, marine species are not capable of converting $18: 3 n-3$ to EPA (20:5n-3) and $18: 2 n-6$ to arachidonic acid (ARA, 20:4n-6); this is due to the fact that marine animals generally have low to negligible enzyme $\Delta-5$ fatty acid desaturase activity $[13,18,19]$ (Figure 1). Since the long chain polyunsaturated fatty acids DHA, EPA and ARA cannot be sufficiently synthesized de novo by marine species,

${ }^{*}$ Corresponding author: Joana Figueiredo, ARC Centre of Excellence for Cora Reef Studies, James Cook University, Australia, E-mail: joana.figueiredo@jcu.edu.au Received May 15, 2012; Accepted June 27, 2012; Published June 02, 2012

Citation: Figueiredo J, Lin J, Anto J, Narciso L(2012) The Consumption of DHA during Embryogenesis as an Indicative of the Need to Supply DHA during Early Larval Development: A Review. J Aquacult Res Dev 3:140 doi:10.4172/21559546.1000140

Copyright: (c) 2012 Figueiredo J, et al. This is an open-access article distributed under the terms of the Creative Commons Attribution License, which permits unrestricted use, distribution, and reproduction in any medium, provided the original author and source are credited. 


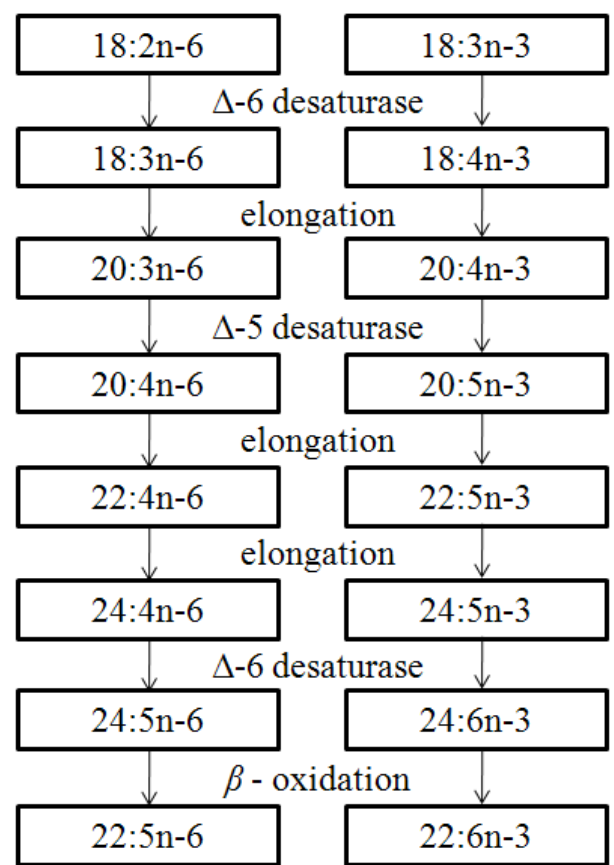

Figure 1: Polyunsaturated fatty acid aerobic pathway in heterotrophic eukaryotic marine organisms.

they are designated by essential fatty acids and must be included in all marine animals' diet $[12,13,20,21]$. Essential fatty acids have important functions on larval development. EPA is effective in promoting larval survival while DHA appears to be particularly important for promoting larval growth (hastening larval duration) and development of neural tissues such as the brain and retina [22-25]. ARA promotes growth, survival and improves resistance to acute stress in marine larvae and post larvae [13].

\section{Advantages and Disadvantages of Different Live Preys}

Rotifers and Artemia nauplii have a small size (generally 0.1-0.5 mm and less than $0.5 \mathrm{~mm}$, respectively), and therefore are adequate as preys in the larval culture of several fish and crustaceans. However, they can be deficient in Eicosapentaenoic Acid (EPA, 20:5n-3), although most common Artemia strains used have a relatively high content of EPA $[7,14,26]$. Both rotifers and Artemia nauplii naturally lack, or have insignificant quantities of, Docosahexaenoic Acid (DHA, 22:6n-3) and are rich in linolenic acid (18:3n-3) and, to a lesser extent, linoleic acid $(18: 2 n-6)[27,28]$. Furthermore, the presence of high amounts of $18: 3 n-$ 3 suppresses the conversion of EPA to DHA. Since failure to provide correct essential fatty acids is a primary cause of unsuccessful culture [29], it is common practice to enrich rotifers and Artemia with essential fatty acids $[7,27,30,31]$. Enrichment consists in feeding an enrichment product rich in the desired essential fatty acids to filter-feeding Artemia and rotifers. This way, one can encapsulate the required essential fatty acids that the prey naturally lacks and create a nutritionally adequate prey. Enrichment products include microalgae, lipid emulsions, fish oils and protists (spray dried single celled heterotrophic marine protist Schizochytrium sp.) [32].

Recent research has focused on the efficacy of using alternative preys, such as ciliates, Barnacle nauplii, nematodes and copepods (alone or in conjunction with traditional prey items), to overcome dietary nutritional deficiencies [33-35]. Copepods are considered the most promising alternative live prey to feed marine fish larvae, due to a preponderance of phospholipids and ratios of DHA: EPA: ARA $[36,37]$ that closely resemble the natural diet of the larvae. Despite the continuous effort to develop protocols to rear copepods in captivity [38-41], their culture in high densities is still unreliable and therefore incapable to support an aquaculture industry.

\section{Larval Nutritional Requirements during Early Larval Development}

Larval nutritional requirements differ between species [12] as a reflection of their dietary and metabolic adaptation to different habitats $[20,42,43]$. Ideally, in culture settings, the nutritional requirement of larvae after the transition from endogenous to exogenous feeding would be known. Unfortunately, this is often not the case. Heming and Buddington [44] hypothesized that the optimal formulation to provide a nutritious diet for first-feeding larvae should replicate the yolk composition of recently spawned eggs. In oviparous organisms, endogenous yolk reserves are responsible for providing nutrients and energy for proper development of the embryo and larvae during the lecithotrophic phase $[43,45]$. Thus, according to Heming and Buddington [44], a larval diet with the same nutritional profile of the recently spawned egg should enhance survival and growth during early larval development. However, it is known that fatty acids are not equally consumed. Furthermore, some fatty acids are consumed, while others can be conserved or even produced during embryogenesis (Figure 1).

Enrichment of prey items with fatty acids to feed the larvae is an expensive procedure in larval culture due to the elevated cost of enrichment products and labor. Most enrichment products contain essential fatty acids, particularly DHA. DHA cannot be synthesized de novo by marine animals and thus it can only be conserved or consumed during embryogenesis. The quantity of DHA necessary to supply to each larval species is usually determined by expensive and laborious trial and errors. Therefore, the development of a fast technique that could indicate the need to supply DHA during early larval development could be quite beneficial for the aquaculture industry.

\section{DHA Consumption During Embryogenesis as an Indicator for DHA-Supply to Larvae}

We hypothesize that the quantity of DHA consumed during embryogenesis is an indicative of the need to supply DHA during early larval development. Specifically, the more DHA consumed during embryogenesis, the greater is the need to supply DHA during early larval development (e.g., through DHA enrichment of nutritionally poor preys or the used of an additional prey with adequate DHA content). Conversely, if the newly spawned eggs are rich in DHA, but this fatty acid is not consumed during embryogenesis, the larval diet might not need to be supplemented with DHA; larvae may be able to successfully develop using solely the DHA conserved through embryogenesis. Note that we are not hypothesizing that this fatty acid is not required; we solely hypothesize that we might not need to supply it in the diet during early larval development. Since DHA is fundamental for the successful development of larvae, the need to supply DHA can be evaluated by comparing larval development success with diets poor and rich in DHA.

\section{Methods for Bibliographic Review}

We focused the literature review on fish and crustaceans species 
Citation: Figueiredo J, Lin J, Anto J, Narciso L(2012) The Consumption of DHA during Embryogenesis as an Indicative of the Need to Supply DHA during Early Larval Development: A Review. J Aquacult Res Dev 3:140 doi:10.4172/2155-9546.1000140

Page 3 of 7

\begin{tabular}{|c|c|c|c|c|}
\hline Species & $\begin{array}{l}\text { Newly } \\
\text { spawned } \\
\text { egg's DHA } \\
\text { content } \\
\left(\mu g \cdot \mathrm{mg} \mathrm{dw}^{-1}\right)\end{array}$ & $\begin{array}{l}\text { DHA con- } \\
\text { sumed during } \\
\text { embryogen- } \\
\text { esis } \\
\left(\mu \mathrm{g} \cdot \mathrm{mg} \mathrm{dw}^{-1}\right)\end{array}$ & $\begin{array}{l}\text { Larval culture } \\
\text { with newly } \\
\text { hatched Arte- } \\
\text { mia nauplii (no } \\
\text { DHA) }\end{array}$ & $\begin{array}{l}\text { Larval culture } \\
\text { with Artemia } \\
\text { nauplii en- } \\
\text { riched or } \\
\text { supplemented } \\
\text { with DHA }\end{array}$ \\
\hline $\begin{array}{l}\text { Armases } \\
\text { cinereum }\end{array}$ & $\begin{array}{l}{[47]} \\
2.64\end{array}$ & NS & $\begin{array}{l}{[48]} \\
86.3 \% \text { survival } \\
(15.2 \text { days })\end{array}$ & ND \\
\hline $\begin{array}{l}\text { Lysmata } \\
\text { seticaudata }\end{array}$ & $\begin{array}{l}{[55]} \\
9.59-12.86\end{array}$ & $\begin{array}{l}{[55]} \\
1.43-4.65\end{array}$ & $\begin{array}{l}{[56,2]} \\
75.41 \% \text { survival } \\
\text { (19 days) }\end{array}$ & $\begin{array}{l}{[56,2]} \\
83.4 \% \text { survival } \\
\text { (19 days) }\end{array}$ \\
\hline $\begin{array}{l}\text { Palaemon } \\
\text { elegans }\end{array}$ & $\begin{array}{l}{[42]} \\
11.8\end{array}$ & $\begin{array}{l}{[42]} \\
2.7\end{array}$ & $\begin{array}{l}{[57,4,58]} \\
88.5-92 \% \\
\text { survival } \\
\text { (12 days) }\end{array}$ & ND \\
\hline $\begin{array}{l}\text { Solea } \\
\text { senegalensis }\end{array}$ & $\begin{array}{l}{[59]} \\
30.7\end{array}$ & $\begin{array}{l}{[59]} \\
2.8\end{array}$ & $\begin{array}{l}{[60,61,62]} \\
29-87 \%(11-19 \\
\text { days) }\end{array}$ & ND \\
\hline $\begin{array}{l}\text { Maja } \\
\text { brachydactyla }\end{array}$ & $\begin{array}{l}{[63]} \\
25.29\end{array}$ & $\begin{array}{l}{[63]} \\
4.97\end{array}$ & $\begin{array}{l}{[64]} \\
18 \% \text { sur- } \\
\text { vival ( } 24 \text { days), } \\
\text { presence } \\
\text { of aberrant } \\
\text { forms, smaller } \\
\text { juveniles }\end{array}$ & $\begin{array}{l}\text { [64] } \\
42.2-46 \% \text { sur- } \\
\text { vival ( } 22 \text { days), } \\
\text { no aberrant } \\
\text { forms, larger } \\
\text { juveniles }\end{array}$ \\
\hline $\begin{array}{l}\text { Palaemon } \\
\text { serratus }\end{array}$ & $\begin{array}{l}{[42,28]} \\
14.84-15.6\end{array}$ & $\begin{array}{l}{[42,28]} \\
8.1-10.37\end{array}$ & $\begin{array}{l}{[28,65]} \\
0-20 \% \text { survival }\end{array}$ & $\begin{array}{l}{[28,65]} \\
73-81 \% \text { survival } \\
\text { and growth }\end{array}$ \\
\hline $\begin{array}{l}\text { Nephrops } \\
\text { norvegicus }\end{array}$ & $\begin{array}{l}{[66]} \\
42.10\end{array}$ & $\begin{array}{l}{[66]} \\
28.29\end{array}$ & {$\left[\begin{array}{l}{[66]} \\
0 \% \text { survival }\end{array}\right.$} & $\begin{array}{l}{[67,68]} \\
0.6 \% \text { survival } \\
(51.7 \text { days })\end{array}$ \\
\hline
\end{tabular}

Table 1: Newly spawned egg's DHA content, DHA consumed during embryogenesis $\left(\mu \mathrm{g} \cdot \mathrm{mg} \mathrm{dw}^{-1}\right)$, and larval culture success with a prey poor or lacking DHA and with a prey enriched with DHA of crustacean and fish species (NS - no significant consumption; ND - no data available; Figueiredo et al. [47]; Staton and Sulkin [48]; Calado et al. [55]; Calado et al. [56]; Figueiredo and Narciso [2]; Morais et al [42]; Rochanaburanon and Williamson [57]; Kumlu and Jones [4]; Sanders et al. [58]; Mourente and Vazquez [59]; Canavate and Fernandez-Diaz [60]; Dinis et al. [61]; Yufera et al. [62]; Figueiredo and Narciso [63]; Urcera et al. [64]; Narciso and Morais [28]; Wickins [65]; Rosa et al. [66]; Figueiredo and Vilela [67]; Rotllant et al. [68]).

which fatty acid content through embryogenesis and larval culture have been previously studied. Specifically we searched for published data on DHA content in newly spawned eggs, DHA consumption during embryogenesis (obtained as the difference between the DHA in newly spawned eggs and pre-hatching eggs), and larval culture success with a prey rich in DHA and with a prey lacking DHA. In order to avoid possible misleading information regarding synthesis and catabolism of fatty acids, data based upon relationships with variable constituents, specifically percent data, were not considered. Only studies in which DHA content was presented as an absolute individual measurement or as a proportion of dry matter ( $\mu \mathrm{g} . \mathrm{mg} \mathrm{dw}-1)$ were considered. Additionally, in order to standardize the data as much as possible, only studies of larval culture using Artemia were considered. Artemia is considered as relatively complete diet, except for the fact that, regardless of its origin or strain, it is poor in DHA (naturally lacks or has a reduced quantity of DHA), but can be easily enriched $[26,46]$. Therefore, studies of survival and growth of larvae fed with (unenriched) Artemia nauplii and DHAenriched Artemia nauplii can be used to compare the effect of a diet poor in DHA and a diet rich in DHA.

\section{Data Available}

A review to the existent data on DHA consumption during embryogenesis, and larval culture success of crustacean and fish species with Artemia nauplii (poor in DHA) and enriched Artemia nauplii (rich in DHA) (summarized on Tables 1 and 2), suggests that the consumption of the essential fatty acid DHA during embryonic development might be a good indicator of the necessity to provide DHA to marine larvae. Overall, existent data shows that greater the consumption of DHA during embryogenesis, the more DHA a larvae requires in its diet to successfully develop (Tables 1 and 2). On the other hand, when DHA is present in newly spawned eggs, but is not significantly consumed through embryogenesis, larvae seem to be equally able to successfully develop with a diet poor in DHA (Tables 1 and 2). However, due to the reduced number of species studied (ten species of crustaceans and three species of fish with data on DHA consumption through embryogenesis and larval culture with Artemia nauplii, unenriched and enriched with DHA, was simultaneously available), further studies are required to confirm these indications.

The newly spawned eggs of all crustacean species contained DHA, but its quantity and consumption through embryogenesis differed between species. The wharf crab Armases cinereum did not significantly consume DHA during embryonic development [47] and its larvae developed successfully with newly hatched Artemia nauplii (poor in DHA) [48]. All the other crustaceans studied (Monaco shrimp Lysmata seticaudata, Rockpool prawn Palaemon elegans, Giant river prawn Macrobrachium rosenbergii, Common prawn Palaemon serratus, Spider crab Maja brachydactyla, Norway lobster Nephrops norvegicus and Shrimp Nauticaris magellanica) consumed DHA during embryogenesis. Overall, as the consumption of DHA during embryogenesis increased, the success of rearing the larvae with a prey poor in DHA decreased. Greater the consumption of DHA during embryogenesis, the greater

\begin{tabular}{|c|c|c|c|c|}
\hline Species & $\begin{array}{l}\text { Newly } \\
\text { spawned } \\
\text { egg's DHA } \\
\text { content } \\
\left(\mu g . \text { ggg }^{-1}\right)\end{array}$ & $\begin{array}{l}\text { DHA con- } \\
\text { sumed during } \\
\text { embryogen- } \\
\text { esis } \\
\left(\mu g \cdot \text { egg }^{-1}\right)\end{array}$ & \begin{tabular}{|l|} 
Larval \\
culture \\
with newly \\
hatched Ar- \\
temia nauplii \\
(no DHA)
\end{tabular} & $\begin{array}{l}\text { Larval culture } \\
\text { with Artemia } \\
\text { nauplii enriched } \\
\text { or supplemented } \\
\text { with DHA }\end{array}$ \\
\hline $\begin{array}{l}\text { Dicentrarchus } \\
\text { labrax }\end{array}$ & $\begin{array}{l}\text { [69] } \\
2 \text { (neutral) } \\
1.2 \text { (phospho- } \\
\text { lipid) }\end{array}$ & NS & $\begin{array}{l}{[70]} \\
80-98.5 \% \\
\text { survival }\end{array}$ & $\begin{array}{l}\text { [71] } \\
84-92 \% \text { survival }\end{array}$ \\
\hline $\begin{array}{l}\text { Nauticaris } \\
\text { magellanica }\end{array}$ & $\begin{array}{l}\text { [72] } \\
0.29-0.37\end{array}$ & $\begin{array}{l}{[72]} \\
0.15-0.16\end{array}$ & ND & $\begin{array}{l}{[73,74]} \\
85.7 \% \text { until zoea } \\
\text { IX, but strong } \\
\text { mortality from } \\
\text { zoea X to de- } \\
\text { capodid stage }\end{array}$ \\
\hline Sparus aurata & $\begin{array}{l}\text { [75] } \\
0.6 \text { (neutral) } \\
0.7 \text { (phospho- } \\
\text { lipid) }\end{array}$ & $\begin{array}{l}\text { [75] } \\
0.15 \text { (neutral) } \\
0.20 \text { (phospho- } \\
\text { lipid) }\end{array}$ & $\begin{array}{l}{[76,77]} \\
15 \% \text { survival }\end{array}$ & $\begin{array}{l}{[76,77,31]} \\
9-28 \% \text { survival }\end{array}$ \\
\hline $\begin{array}{l}\text { Macro- } \\
\text { brachium } \\
\text { rosenbergii }\end{array}$ & $\begin{array}{l}{[78]} \\
0.67\end{array}$ & $\begin{array}{l}{[78]} \\
0.42\end{array}$ & $\begin{array}{l}{[79,80,81]} \\
44 \% \text { survival }\end{array}$ & $\begin{array}{l}{[79,80,81]} \\
56 \% \text { survival }\end{array}$ \\
\hline
\end{tabular}

Table 2: Newly spawned egg's DHA content, DHA consumed during embryogenesis $\left(\mu{\mathrm{g} . \mathrm{egg}^{-1}}^{-1}\right)$, and larval culture success with a prey poor or lacking DHA and with a prey enriched with DHA of crustacean and fish species (NS - no significant consumption; ND - no data available; Rønnestad et al. [69]; Navarro et al. [70] Navarro et al. [71]; Wehrtmann and Kattner [72]; Wehrtmann and Albornoz [73] Wehrtmann and Albornoz [74]; Rønnestad et al. [75]; Robin and Vincent [76]; Robin and Peron [77]; Monroig et al. [31]; Clarke et al. [78]; Devresse et al. [79]; Alam et al. [80]; Alam et al. [81]). 
Citation: Figueiredo J, Lin J, Anto J, Narciso L(2012) The Consumption of DHA during Embryogenesis as an Indicative of the Need to Supply DHA during Early Larval Development: A Review. J Aquacult Res Dev 3:140 doi:10.4172/2155-9546.1000140

was the relative success of feeding larvae with a prey rich in DHA. It is important to notice that the Norway lobster (or scampi) Nephrops norvegicus consume a very high amount of DHA during embryogenesis, thus we suggest the larvae require a prey with a much greater DHA content than the one provided in the existent study. The larval culture failure of the shrimp Nauticaris magellanica past zoea IX is probably due to the increase or change in nutritional requirements during late development.

The larvae of the three fish species studied (sea bream Sparus aurata, sole Solea senegalensis and European sea bass Dicentrarchus labrax) exhibit a similar pattern of DHA consumption during embryogenesis and requirement of DHA during early larval development.

\section{General Conclusions}

Available data suggests that the more a species consumes DHA ( $\mu$ g. egg $^{-1}$ or $\mu$ g.mg dw ${ }^{-1}$ ) during the embryonic development the more it will require diet rich in DHA during early larval development (Tables 1 and 2). If the newly spawned egg has DHA, but no significant consumption of DHA during embryogenesis occurs, larval survival and growth do not seem to be greatly affected when larvae are fed with a DHA-poor prey (Tables 1 and 2).

Species which recently spawned eggs contain DHA, but that do not consume DHA during embryogenesis, probably do not need to be fed with a DHA-rich prey during early larval development because they still have DHA reserves. Later in development, when their DHA reserves are exhausted, they will likely require a diet rich in DHA; but, by that time, since they are more developed, this essential fatty acid may be provided, for example, as a pellet food. As the consumption of DHA during embryogenesis increases, the greater may have to be the quantity of DHA provided through the diet to the larvae. The DHA consumption during embryogenesis can provide the producers with an indication for DHA requirements during early larval development. Since enrichment and enrichment products are expensive, a better knowledge of the quantity of DHA required for larvae to successfully develop can avoid unnecessary expenses, and contribute to the establishment of a profitable methodology.

\section{Future Studies and its Possible Implications}

Despite our hypothesis being supported by all published studies, existing data is still insufficient to draw a definite conclusion, and more studies are needed to confirm it. Moreover, larval culture success is due to a combination of multiple aspects, such as larval culture conditions and larval diet composition, particularly EFA (and their relative proportions, DHA:EPA:ARA) $[3,20,23,29]$; but, since DHA is an essential fatty acid and we only compared studies that used the same prey (Artemia nauplii), which composition is well known, our conclusions will likely stand to further studies. We suggest that a set of standardized and controlled experiments across a significant range of species are still required to test the hypothesis that information on DHA consumption during embryogenesis could be used to develop and/or improve the larval diets and reduce productions costs. Furthers studies should: 1) determine the DHA consumption through embryogenesis (i.e., determine DHA in newly spawned and pre-hatching eggs of wild individuals), 2) culture larvae fed the same prey enriched with different known quantities of DHA, while controlling for DHA:EPA:ARA ratios, and larval survival, growth and presence of abnormalities registered (long-term effects of feeding a DHA-poor diet should also be determined), and 3) the results for multiple species should be compared to determine if the DHA consumption during embryogenesis could be an indicator of the DHA content required in the larval diet. If this hypothesis was validated, a relatively simple procedure of determining fatty acid consumption during embryogenesis could: (1) avoid expensive and laborious trial and errors to find the most nutritionally suitable diet for larvae, (2) lead to a faster development of profitable larval aquaculture feeds for some species, and (3) potentially minimize enrichment (and its cost) to the strictly necessary.

For now, the consumption of DHA during embryogenesis can be used as a "rule of thumb" to decide whether, and to which extent, the larvae may need DHA in their diet, and thus possibly contribute to a faster development of culture protocols for novel species of interest

\begin{tabular}{|c|c|c|}
\hline Species & $\begin{array}{l}\text { Newly spawned egg's } \\
\text { DHA content } \\
\left(\mu \mathrm{g} \cdot \mathrm{mg} \mathrm{dw}^{-1}\right)\end{array}$ & $\begin{array}{l}\text { DHA consumed during } \\
\text { embryogenesis } \\
\left(\mu \mathrm{g} \cdot \mathrm{mg} \mathrm{dw}^{-1}\right)\end{array}$ \\
\hline Uca rapax & $\begin{array}{l}{[49]} \\
2.6\end{array}$ & NS \\
\hline Uca annulipes & $\begin{array}{l}{[50,51]} \\
0.77-2.74\end{array}$ & $\begin{array}{l}\text { [50,51] } \\
\text { NS }\end{array}$ \\
\hline Uca inversa & $\begin{array}{l}{[50]} \\
4.1\end{array}$ & $\begin{array}{l}{[50]} \\
\text { NS }\end{array}$ \\
\hline Uca urvillei & $\begin{array}{l}{[50]} \\
2.0\end{array}$ & $\begin{array}{l}\text { [50] } \\
\text { NS }\end{array}$ \\
\hline $\begin{array}{l}\text { Uca chloroph- } \\
\text { thalmus }\end{array}$ & $\begin{array}{l}{[50]} \\
2.4\end{array}$ & $\begin{array}{l}\text { [50] } \\
\text { NS }\end{array}$ \\
\hline Uca vocans & $\begin{array}{l}{[50]} \\
3.9\end{array}$ & $\begin{array}{l}\text { [50] } \\
\text { NS }\end{array}$ \\
\hline $\begin{array}{l}\text { Palaemon } \\
\text { concinnus }\end{array}$ & $\begin{array}{l}\text { [82] } \\
8.6-15.7\end{array}$ & $\begin{array}{l}\text { [82] } \\
\text { NS-7.7 }\end{array}$ \\
\hline $\begin{array}{l}\text { Chlorotocus } \\
\text { crassicornis }\end{array}$ & $\begin{array}{l}{[43]} \\
15.1\end{array}$ & $\mid \begin{array}{l}{[43]} \\
1.4-4.6\end{array}$ \\
\hline $\begin{array}{l}\text { Macropipus } \\
\text { tuberculatus }\end{array}$ & $\begin{array}{l}{[43]} \\
17.2\end{array}$ & $\begin{array}{l}{[43]} \\
2.9\end{array}$ \\
\hline $\begin{array}{l}\text { Plesionika } \\
\text { narval }\end{array}$ & $\begin{array}{l}{[83]} \\
10.7\end{array}$ & $\begin{array}{l}{[83]} \\
4.5\end{array}$ \\
\hline $\begin{array}{l}\text { Plesionika } \\
\text { martia martia }\end{array}$ & $\begin{array}{l}{[43,42]} \\
20.5-24.5\end{array}$ & {$\left[\begin{array}{l}{[43,42]} \\
5.3-6.7\end{array}\right.$} \\
\hline Sarda sarda & $\begin{array}{l}{[84]} \\
32.7\end{array}$ & $\begin{array}{l}{[84]} \\
5.7\end{array}$ \\
\hline $\begin{array}{l}\text { Hippocampus } \\
\text { guttulatus }\end{array}$ & $\begin{array}{l}{[85]} \\
17.3\end{array}$ & $\begin{array}{l}{[85]} \\
11.7\end{array}$ \\
\hline $\begin{array}{l}\text { Polybius } \\
\text { henslowii }\end{array}$ & $\begin{array}{l}{[43]} \\
34.4\end{array}$ & $\begin{array}{l}{[43]} \\
13.9\end{array}$ \\
\hline Dentex dentex & $\begin{array}{l}{[86]} \\
43.3\end{array}$ & $\begin{array}{l}{[86]} \\
16.6\end{array}$ \\
\hline $\begin{array}{l}\text { Homarus gam- } \\
\text { marus }\end{array}$ & $\begin{array}{l}{[87]} \\
29.9\end{array}$ & $\begin{array}{l}{[87]} \\
20.4\end{array}$ \\
\hline
\end{tabular}

Table 3: Newly spawned egg's DHA content and DHA consumed during embryogenesis $\left(\mu \mathrm{g} . \mathrm{mg} \mathrm{dw}^{-1}\right)$ (NS - no significant consumption; Figueiredo et al. [49]; Torres et al. [50]; Penha-Lopes et al. [51]; Penha-Lopes et al. [82]; Rosa et al. [43]; Guerao and Abello [83]; Morais et al. [42]; Ortega and Mourente [84]; Faleiro and Narciso [85]; Mourente et al. [86]; Rosa et al. [87]) 
Citation: Figueiredo J, Lin J, Anto J, Narciso L(2012) The Consumption of DHA during Embryogenesis as an Indicative of the Need to Supply DHA during Early Larval Development: A Review. J Aquacult Res Dev 3:140 doi:10.4172/2155-9546.1000140

to aquaculture. For example, there are several species of fish and crustacean which DHA consumption through embryogenesis has been studied (summarized in Table 3) and for which we can make predictions about the DHA requirements of the larvae. Provided the newly hatched larvae are able to readily feed on Artemia nauplii, we expect that Uca larvae will not require Artemia nauplii to be enriched with DHA to successfully develop [49-51] (Table 3). Newly spawned Artemia nauplii have been used in the past to rear the larvae of Uca sp. [52], but survival and growth data was never reported. The species that consume a significant amount of DHA during embryogenesis, such as shrimp Plesionika narval and P. martia, Atlantic bonito Sarda sarda, Seahorse Hippocampus guttulatus, Henslow's swimming crab Polybus henslowii, will probably require a diet rich in DHA to complete development. Common dentex Dentex dentex and the European lobster Homarus gammarus consume a very significant amount of DHA during embryogenesis (similar to Nephrops norvegicus), therefore a DHAenriched Artemia might still be an insufficient source of DHA. Rueda and Martinez [53] reported that Dentex dentex displays high mortality and presents malformations when fed rotifers and Artemia and requires a diet more rich in DHA, which is coherent with our hypothesis. When Homarus gammarus larvae are fed newly hatched Artemia nauplii and mysids, they do not complete larval development [54].

\section{Acknowledgments}

We thank Fundação para a Ciência e a Tecnologia and Portuguese Government the financial support provided to the authors (SFRH/BD/17130/2004)

\section{References}

1. Figueiredo J, Penha-Lopes G, Lin J, Narciso L (2008) Productivity and profitability of Mithraculus forceps aquaculture. Aquaculture 283: 43-49.

2. Figueiredo J, Narciso L (2006) Productivity improvement of Lysmata seticaudata larval rearing protocol through modelling. Aquaculture 261: 1249-1258.

3. Blaxter JHS (1986) Development of sense organs and behaviour of teleost larvae with special reference to feeding and predator avoidance. Trans Amer Fish Soc 115: 98-114

4. Kumlu M, Jones DA (1995) Feeding and digestion in the caridean shrimp larva of Palaemon elegans Rathke and Macrobrachium rosenbergii (De Man) (Crustacea: Palaemonidae) on live and artificial diets. Aquaculture Nutrition 1: 3-12.

5. Kumlu M, Jones DA (1995) The effect of live and artificial diets on growth, survival, and trypsin activity in larvae of Penaeus indicus. J World Aquac Soc 26: 406-415.

6. Cahu C, Zambonino-Infante (2001) Substitution of live food by formulated diets in marine fish larvae. Aquaculture 200: 161-180.

7. Dhert P, Rombaut G, Suantika G, Sorgeloos P (2001) Advancement of rotifer culture and manipulation techniques in Europe. Aquaculture 200: 129-146.

8. Hagiwara A, Gallardo WG, Assavaaree M, Kotani T, de Araujo AB (2001) Live food production in Japan: recent progress and future aspects. Aquaculture 200: 111-127.

9. Harrison KE (1990) The role of nutrition in maturation, reproduction and embryonic development of decapod crustaceans: a review. J Shellfish Res 9: 1-28.

10. Anger K (1998) Patterns of growth and chemical composition in decapod crustacean larvae. Invertebr Repr Dev 33: 159-176

11. Bergé JP, Barnathan G (2005) Fatty acids from lipids of marine organisms: molecular biodiversity, roles as biomarkers, biologically active compounds, and economical aspects. Adv Biochem Engin Biotechnol 96: 49-125.

12. Sargent JR, Henderson RJ, Tocher DR (1989) The lipids. In: Halver J.E. (ed) Fish Nutrition. Academic, New York, 153-218.

13. Bell JG, Sargent JR (2003) Arachidonic acid in aquaculture feeds: current status and future opportunities. Aquaculture 218: 491-499.

14. Sargent JR, McEvoy LA, Bell JG (1997) Requirements, presentation and sources of polyunsaturated fatty acids in marine fish larval feeds. Aquaculture 155: $117-127$.
15. Voss A, Reinhart M, Sankarappa S, Sprecher H (1991) The metabolism of 7 , $10,13,16,19$-docosapentaenoic acid to $4,7,10,13,16,19$-docosahexaenoic acid in rate liver is independent of a 4-desaturase. J Biol Chem 266: 1999520000.

16. Teshima SI, Kanazawa A, Koshio S (1992) Ability for bioconversion of $n-3$ fatty acids in fish and crustaceans. Océanis 18: 67-75.

17. Buzzi M, Henderson RJ, Sargent JR (1996) The desaturation and elongation of linolenic acid and eicosapentaenoic by hepatocytes and liver microsomes from rainbow trout (Oncorhyncus mykiss) fed diets containing fish oil or olive oil. Biochim Biophys Acta 1299: 235-244.

18. Ghioni C, Tocher DR, Bell MV, Dick JR, Sargent DR (1999) Low $C_{18}$ to $C_{20}$ fatty acid elongase activity and limited conversion of stearidonic acid, 18:4n-3, to eicosapentaenoic acid, 20:5n-3, in a cell line from the turbot, Scophthalmus maximus. Biochim Byophys Acta 1437: 170-181.

19. Tocher DR, Ghioni C (1999) Fatty acid metabolism in marine fish: low activity of $\Delta 5$ desaturation in gilthead sea bream (Sparus aurata) cells. Lipids 34: 433 440

20. Sargent J, Bell G, McEvoy LA, Tocher DL, Estevez A (1999) Recent developments in the essential fatty acid nutrition of fish. Aquaculture 177: 191-199.

21. Anger K (2001) The biology of decapod crustacean larvae. In: Vonk R, (ed) Crustacean Issues, vol14. A. A. Balkema Publishers, Lisse, The Netherland.

22. Mourente G, Rodriguez A, Tocher DR, Sargent JR (1993) Effects of dietary docosahexaenoic acid (DHA; 22:6n-3) on lipid and fatty acid compositions and growth in gilthead sea bream (Sparus aurata L.) larvae during first feeding Aquaculture 112: 79-98.

23. Bell MV, Batty RS, Dick JR, Fretwell K, Navarro JC, et al. (1995) Dietary deficiency of docosahaexaenoic acid impairs vision at low light intensities in juvenile herring (Clupea harengus L.). Lipids 30: 443-449.

24. Jones DA, Yule AB, Holland DL (1997) Larval nutrition. In: D'Abramo, L.R. Conklin, D.E., Akiyama, D. M. (Eds.) Advances in World Aquaculture 6 - Crustacean Nutrition. Baton Rouge, Louisiana, USA, World Aquaculture Society, Louisiana State University, 353-389.

25. Sulkin SD, McKeen GL (1999) The significance of feeding history on the value of heterotrophic microzooplankton as prey for larval crabs. Mar Ecol Prog Ser 186: $219-225$

26. Sorgeloos P, Dhert P, Candreva P (2001) Use of the brine shrimp, Artemia spp. in marine fish larviculture. Aquaculture 200: 147-159.

27. Fernández-Reiriz MJ, Labarta U, Ferreiro MJ (1993) Effects of commercia enrichment diets on the nutritional value of the rotifer (Brachionus plicatilis). Aquaculture 112: 195-206.

28. Narciso L, Morais S (2001) Fatty acid profile of Palaemon serratus (Palaemonidae) eggs and larvae during embryonic and larval development using different live diets. J Crust Biol 21: 566-574.

29. Rainuzzo JR, Reitan KI, Olsen Y (1997) The significance of lipids at early stages of marine fish: a review. Aquaculture 155: 103-115

30. Han K, Geurden I, Sorgeloos P (2000) Enrichment strategies for Artemia using emulsions providing different levels of $n-3$ highly unsaturated fatty acids. Aquaculture 183: 335-347.

31. Monroig O, Navarro JC, Amat F, González P, Bermejo A, et al. (2006) Enrichment of Artemia nauplii in essential fatty acids with different types of liposomes and their use in the rearing of gilthead sea bream (Sparus aurata) larvae. Aquaculture 251: 491-508.

32. Sargent J, McEvoy L, Estevez A, Bell G, Bell M, et al. (1999) Lipid nutrition of marine fish during early development: current status and future directions. Aquaculture 179: 217-229.

33. Shields RJ, Bell G, Luizi FS, Gara B, Bromage NR, et al. (1999) Natural copepods are superior to enriched Artemia nauplii as feeds for halibut larvae (Hippoglossus hippoglossus) in terms of survival, pigmentation, and retinal morphology: relation to dietary essential fatty acids. J Nutr 129: 1186-1194.

34. Bamstedt U, Wild B, Martinussen MB (2001) Significance of food type for growth of ephyrae Aurelia aurita (Scyphozoa). Mar Biol 139: 641-650.

35. Rajkumar M, Kumaraguru KP (2006) Suitability of the copepod, Acartia clausi as a live feed for Seabass larvae (Lates calcarifer Bloch): Compared to traditional live-food organisms with special emphasis on the nutritional value. Aquaculture 261: 649-658. 
Citation: Figueiredo J, Lin J, Anto J, Narciso L(2012) The Consumption of DHA during Embryogenesis as an Indicative of the Need to Supply DHA during Early Larval Development: A Review. J Aquacult Res Dev 3:140 doi:10.4172/2155-9546.1000140

36. Bell JG, McEvoy LA, Estevez A, Shields RJ, Sargent JR (2003) Optimising lipid nutrition in first-feeding flatfish larvae. Aquaculture 227: 211-220.

37. Sørensen TF, Drillet G, Engell-Sørensen K, Hansen BW, Ramløv H (2007) Production and biochemical composition of eggs from neritic calanoid copepods reared in large outdoor tanks (Limfjord, Denmark). Aquaculture 263: 84-96.

38. Payne MF, Rippingale RJ (2000) Evaluation of diets for culture of the calanoid copepod Gladioferens imparipes. Aquaculture 187: 85-96.

39. Chen Q, Sheng J, Lin Q, Gao Y, Lv J (2006) Effect of salinity on reproduction and survival of the copepod Pseudodiaptomus annandalei Sewell, 1919. Aquaculture 258: $575-582$

40. Peck MA, Holste L (2006) Effects of salinity, photoperiod and adult stocking density on egg production and egg hatching success in Acartia tonsa (Calanoida: Copepoda): Optimizing intensive cultures. Aquaculture 255: 341-350.

41. Jepsen PM, Andersen N, Holm T, Jørgensen AT, Højgaard JK, et al. (2007) Effects of adult stocking density on egg production and viability in cultures of the calanoid copepod Acartia tonsa (Dana). Aquac Res 38: 764-772.

42. Morais S, Narciso L, Calado R, Nunes ML, Rosa R (2002) Lipid dynamics during the embryonic development of Plesionika martia martia (Decapoda: Pandalidae), Palaemon serratus and Palaemon elegans (Decapoda: Palaemonidae): relation to metabolic consumption. Mar Ecol Prog Ser 242: 195-204.

43. Rosa R, Calado R, Narciso L, Nunes ML (2007) Embryogenesis of decapod crustaceans with different life history traits, feeding ecologies and habitats: a fatty acid approach. Mar Biol 151: 935-947.

44. Heming TA, Buddington RK (1988) Yolk absorption in larval fishes. In: Hoar WS Randall DJ (eds), Fish Physiology. Academic Press, London, XI, pp407-446.

45. Subramoniam T (1991) Yolk utilization and esterase activity in the mole crab Emerita asiatica (Milne Edwards). In: Schram FR (ed) Crustacean Egg Production, Crustacean Issues, 7. AA Balkema Publishers, 19-30

46. Figueiredo J, van Woesik R, Lin J, Narciso L (2009) Artemia franciscana enrichment model - How to keep them small, rich and alive? Aquaculture 294 212-220.

47. Figueiredo J, Penha-Lopes G, Anto J, Narciso L, Lin J (2008) Fecundity, Brood loss and egg development through embryogenesis of Armases cinereum (Decapoda: Grapsidae). Mar Biol 154: 287-294.

48. Staton JL, Sulkin SD (1991) Nutritional requirements and starvation resistance in larvae of the brachyuran crabs Sesarma cinereum (Bosc) and S. reticulatum (Say). J Exp Mar Biol Ecol 152: 271-284

49. Figueiredo J, Penha-Lopes G, Anto J, Narciso L, Lin J (2008) Potential fertility and egg development (volume, water, lipid, and fatty acid content) through embryogenesis of Uca rapax (Decapoda: Brachyura: Ocypodidae). J Crust Bio 28: $528-533$

50. Torres P, Penha-Lopes G, Narciso L, Macia A, Paula J (2008) Fatty acids dynamics during embryogenic development in genus Uca (Brachyura: Ocypodidae), from mangroves of Inhaca Island, Mozambique. Estuar Coast Shelf S 80: $307-313$

51. Penha-Lopes G, Torres P, Narciso L, Cannicci S, Paula J (2009) Comparison of fecundity, embryo loss and fatty acid composition of mangrove crab species in sewage contaminated and pristine mangrove habitats in Mozambique. J Exp Mar Biol Ecol 381: 25-32.

52. Paula J, Dornelas M, Flores AAV (2003) Stratified settlement and moulting competency of brachyuran megalopae in Ponta Rasa mangrove swamp, Inhaca Island (Mozambique). Estuar Coast Shelf Sci 56: 325-337

53. Rueda FM, Martínez FJ (2001) A review on the biology and potential aquaculture of Dentex dentex. Rev Fish Biol Fisher 11: 57-70.

54. Wickins JF, Beard TW, Child AR (1995) Maximizing lobster, Homarus gammarus (L.), egg and larval viability. Aquac Res 26: 379-392.

55. Calado R, Rosa R, Nunes ML, Narciso L (2005) Amino and fatty acid dynamics of Lysmata seticaudata (Decapoda: Hippolytidae) embryos during early and late reproductive season. Mar Biol 147: 341-351.

56. Calado R, Figueiredo J, Rosa R, Nunes ML, Narciso L (2005b) Effects of temperature, density and diet on development, survival, settlement synchronism, and fatty acid profile of the ornamental shrimp Lysmata seticaudata. Aquaculture 245: 221- 237

57. Rochanaburanon T, Williamson DI (1976) Laboratory survival of larvae of Pala- emon elegans Rathke and other caridean shrimps in relation to their distribution and Ecology. Estuar Coast Mar Sci 4: 83-91.

58. Sanders MB, Billinghurst Z, Depledge MH, Clare AS (2005) Larval development and vitellin-like protein expression in Palaemon elegans larvae following xeno-oestrogen exposure. Integrative Comp Biol 45: 51-60.

59. Mourente G, Vázquez R (1996) Changes in the content of total lipid, lipid classes and their fatty acids of developing eggs and unfed larvae of the Senegal sole, Solea senegalensis Kaup. Fish Physiol Biochem 15: 221-235.

60. Canavate J (1999) Influence of co-feeding larvae with live and inert diets on weaning the sole Solea senegalensis onto commercial dry feeds. Aquaculture 174: 255-263.

61. Dinis MT, Ribeiro L, Soares F, Sarasquete C (1999) A review on the cultivation potential of Solea senegalensis in Spain and in Portugal. Aquaculture 176: 27 38.

62. Yúfera M, Parra G, Santiago R, Carrascosa M (1999) Growth, carbon, nitrogen and caloric content of Solea senegalensis (Pisces: Soleidae) from egg fertilization to metamorphosis. Mar Biol 134: 43-49.

63. Figueiredo J, Narciso L (2008) Egg volume, energy content, and fatty acid profile of Maja brachydactyla (Crustacea: Brachyura: Majidae) during embryogenesis. J Mar Biol Assoc UK 88: 1401-1405.

64. Urcera MJ, Arnaiz R, Rua N, Coo A (1993) Cultivo de la centolla Maja squinado: Influencia de la dieta en el desarrollo larvario. Actas IV Congresso Nac Acuicult. 269-274.

65. Wickins JF (1972) The food value of Brine Shrimp, Artemia salin aL., to larvae of the prawn, Palaemon serratus Pennant. J Exp Mar Biol Ecol 10: 151-170.

66. Rosa R, Morais S, Calado R, Narciso L, Nunes ML (2003) Biochemical changes during the embryonic development of Norway lobster, Nephrops norvegicus. Aquaculture 221: 507-522.

67. Figueiredo MJ, Vilela MH (1972) On the artificial culture of Nephrops norvegicus reared from the egg. Aquaculture 1: 173-180.

68. Rotllant G, Charmantier-Daures M, Charmantier G, Anger K, Sardà F (2001) Effects of diet on Nephrops norvegicus (L.) larval and postlarval development growth, and elemental composition. J Shellfish Res 20: 347-352.

69. Rønnestad I, Koven W, Tandler A, Harel M, Fyhn HJ (1998). Utilization of yolk fuels in developing eggs and larvae of European sea bass (Dicentrarchus la brax). Aquaculture 162: 157-170.

70. Navarro JC, Hontoria F, Varo I, Amat F (1988) Effect of alternate feeding with poor long-chain polyunsaturated fatty acid Artemia strain and a rich one for sea bass (Dicentrarchus labrax) and prawn (Penaeus kerathurus) larvae. Aquaculture $74: 307-317$

71. Navarro JC, McEvoy LA, Amat F, Sargent JR (1995) Effects of diet on fatty acid composition of body zones in larvae of the sea bass Dicentrarchus labrax: a chemometric study. Mar Biol 124: 177-183.

72. Wehrtmann IS, Kattner G (1998) Changes in volume, biomass, and fatty acids of developing eggs in Nauticaris magellanica (Decapoda: Caridea): a latitudinal comparison. J Crust Biol 18: 413-422.

73. Wehrtmann IS, Albornoz L (1998) Larval development of Nauticaris magellanica (A. Milne Edwards, 1891) (Decapoda: Caridea: Hippolytidae), reared unde laboratory conditions. Bull Mar Sci 62: 45-72

74. Wehrtmann IS, Albornoz L (2003) Larvae of Nauticaris magellanica (Decapoda Caridea: Hippolytidae) reared in the laboratory differ morphologically from those in nature. J Mar Biol Assoc UK 83: 949-957.

75. Rønnestad I, Koven WM, Tandler A, Harel M, Fyhn HJ (1994) Energy metabolism during development of eggs and larvae of gilthead sea bream (Sparus aurata). Mar Biol 120: 187-196.

76. Robin JH, Vincent B (2003) Microparticulate diets as first food for gilthead sea bream larva (Sparus aurata): study of fatty acid incorporation. Aquaculture 225 463-474.

77. Robin JH, Peron A (2004) Consumption vs. deposition of essential fatty acids in gilthead sea bream (Sparus aurata) larvae fed semi-purified diets. Aquaculture 238: 283-294.

78. Clarke A, Brown JH, Holmes LJ (1990) The biochemical composition of eggs from Macrobrachium rosenbergii in relation to embryonic development. Comp Biochem Physiol 96: 505-511. 
Citation: Figueiredo J, Lin J, Anto J, Narciso L(2012) The Consumption of DHA during Embryogenesis as an Indicative of the Need to Supply DHA during Early Larval Development: A Review. J Aquacult Res Dev 3:140 doi:10.4172/2155-9546.1000140

Page 7 of 7

79. Devresse B, Romdhane MS, Buzzi M, Rasowo J, Léger P, et al. (1990) Improved larviculture outputs in the giant freshwater Macrobrachium rosenbergii fed a diet of Artemia enriched with n-3 HUFA and phospholipids. World Aquac 21: 123-125

80. Alam MJ, Ang KJ, Cheah SH (1993) Use of Moina micrura (Kurz) as an Artemia substitute in the production of Macrobrachium rosenbergii (de Man) postlarvae. Aquaculture 109: 337-349.

81. Alam MJ, Ang KJ, Begum M (1995) Use of egg custard augmented with cod liver oil and Moina micrura on production of freshwater prawn postlarvae. Aquac Int 3: 249-259.

82. Penha-Lopes G, Torres P, Cannicci S, Narciso L, Paula J (2011) Monitoring anthropogenic sewage pollution on mangrove creeks in southern Mozambique: A test of Palaemon concinnus Dana, 1852 (Palaemonidae) as a biological indicator. Environ Pollut 159: 636-645.

83. Guerao G, Abelló P (1999) Morphology of the early zoeal stages of Macropipus tuberculatus (Roux, 1830) (Crustacea, Brachyura, Portunidae). J Plankton Res 21: 1993-2008.

84. Ortega A, Mourente G (2010) Comparison of the lipid profiles from wild caught eggs and unfed larvae of two scombroid fish: northern bluefin tuna (Thynnus thynnus L., 1758) and Atlantic bonito (Sarda sarda Bloch, 1793). Fish Physiol Biochem 36: 461-471.

85. Faleiro F, Narciso L (2010) Lipid dynamics during early development of Hippocampus guttulatus seahorses: Searching for clues on fatty acid requirements. Aquaculture 307: 56-64.

86. Mourente G, Rodríguez A, Grau A, Pastor E (1999) Utilization of lipids by Dentex dentex $\mathrm{L}$. (Osteichthyes, Sparidae) larvae during lecitotrophia and subsequent starvation. Fish Physiol Biochem 21: 45-58.

87. Rosa R, Calado R, Andrade AM, Narciso L, Nunes ML (2005) Changes in amino acids and lipids during embryogenesis of European lobster, Homarus gammarus (Crustacea: Decapoda). Comp Biochem Physiol B Biochem Mol Bio 140: 241-249. 